\title{
Profil Berpikir Relasional Siswa Visual Berdasarkan Gender dalam Menyelesaikan Masalah Matematika
}

\author{
Nurrahmah ${ }^{1}$, Hery Susanto ${ }^{1}$, Hendro Permadi ${ }^{1}$ \\ ${ }^{1}$ Pendidikan Matematika-Universitas Negeri Malang
}

\begin{tabular}{l}
\hline \hline INFO ARTIKEL \\
\hline Riwayat Artikel: \\
Diterima: 14-05-2019 \\
Disetujui: $19-11-2019$ \\
\hline
\end{tabular}

\section{Kata kunci:}

relational thinking; problem solving; visual learning style; gender differences; berpikir relasional; penyelesaian masalah; gaya belajar visual; perbedaan gender

\begin{abstract}
ABSTRAK
Abstract: This study aimed to describe the relational thinking of male and female visual students in solving mathematical problems. The method used is descriptive analysis. Subjects in this study were 1 male student and 1 female student who had visual learning style. The instruments consists a learning style questionnaires, test questions and interview guidelines. The results showed that visual male students who were able to see equal to $(=)$ as relation symbol, could focus on the expression structure and could provide rationality the problem solving strategy. However, male visual students have not been able to focus on structure because students make computational errors.
\end{abstract}

\begin{abstract}
Abstrak: Penelitian ini bertujuan untuk mendeskripsikan berpikir relasional siswa visual laki-laki dan perempuan dalam menyelesaikan masalah matematika. Metode yang digunakan adalah analisis deskriptif. Subjek pada penelitian ini adalah satu siswa laki-laki dan satu siswa perempuan yang memilki gaya belajar visual. Instrumen berupa angket gaya belajar, soal tes, dan pedoman wawancara. Hasil penelitian menunjukkan siswa visual laki-laki maupun perempuan mampu melihat tanda sama dengan $(=)$ sebagai simbol relasi, dapat fokus pada struktur ekspresi dan dapat memberikan rasionalitas penggunaan strategi penyelesaian masalah. Namun, siswa visual laki-laki belum mampu fokus pada struktur ekspresi karena siswa melakukan kesalahan komputasi.
\end{abstract}

\author{
Alamat Korespondensi: \\ Nurrahmah \\ Pendidikan Matematika \\ Universitas Negeri Malang \\ Jalan Semarang 5 Malang \\ E-mail: rahmahbim4@gmail.com
}

Penyelesaian masalah merupakan salah satu aspek penting dalam pembelajaran matematika. Pentingnya penyelesaian masalah di Indonesia tercermin dalam kurikulum, yaitu pada standar kompetensi lulusan (Permendikbud Nomor 20 Tahun 2016), dimana kemampuan menyelesaikan masalah merupakan aspek kompetensi yang harus dikuasai oleh siswa di Indonesia. Pentingnya penyelesaian masalah juga diungkapkan oleh National Council of Teachers of Mathematics bahwa melalui penyelesaian masalah, siswa dapat memperoleh cara berpikir, menumbuhkan kebiasaan untuk tekun, menumbuhkan rasa ingin tahu yang besar, dan kepercayaan diri dalam situasi apapun (NCTM, 2000).

Penyelesaian masalah pada dasarnya bukanlah aktivitas yang seragam dan monoton karena penyelesaian masalah dipengaruhi oleh beberapa faktor salah satunya adalah cara menyajikan masalah ke penyelesaian masalah (Baiduri dkk, 2013). Untuk dapat menyajikan masalah ke penyelesaian, siswa memerlukan suatu pendekatan. Menurut Hejny, dkk (2006), terdapat dua pendekatan dalam menyelesaikan masalah yaitu meta-strategi prosedural (procedural meta-strategy) dan meta-strategi konseptual (conceptual meta-strategy). Siswa yang menggunakan meta-strategi konseptual dalam menyelesaikan masalah dikatakan berpikir relasional (Molina, dkk, 2008; Stephens, 2006). Berpikir relasional merupakan salah satu aspek penting dalam penyelesaian masalah karena ketika menyelesaikan masalah yang diberikan, siswa membangun hubungan antara pengetahuan mengenai struktur atau sifat-sifat yang baru serta pengetahuan yang sebelumnya diajarkan sehingga diperoleh suatu kesimpulan yang dikehendaki (Baiduri, dkk, 2013).

Di sisi lain, proses penyelesaian masalah juga dipengaruhi oleh perbedaan individu (Baiduri, dkk, 2013). Perbedaan individu terdiri dari beberapa jenis, di antaranya perbedaan gender, perbedaan kemampuan, perbedaan kepribadian, dan perbedaan gaya belajar (Sugiyono, 2009). Menurut Indrawati (2017) perbedaan gaya belajar akan meyebabkan perbedaan kemampuan siswa dalam mengolah, menyelesaikan masalah, dan berpengaruh terhadap respons siswa ketika menyelesaikan masalah matematika. Selain itu, hasil penelitian Zulyanty (2016) menunjukkan bahwa kemampuan siswa dalam menyelesaikan masalah dipengaruhi oleh gaya belajar. Hal ini menunjukkan bahwa gaya belajar memengaruhi siswa dalam menyelesaikan masalah matematika. 
Memahami gaya belajar yang dimiliki oleh siswa sangat penting bagi guru. Hal terrsebut dikarenakan pemahaman terdapat gaya belajar dapat dimanfaatkan oleh guru untuk mengenal siswa sehingga dapat mengoptimalkan pengetahuan yang akan diterima oleh siswa pada proses pembelajaran (Garner \& Harrison, 2013). Salah satu gaya belajar yang dimiliki oleh siswa adalah gaya belajar visual. Siswa yang memliki gaya belajar visual biasanya belajar dengan cara melihat, mengamati, memandang, atau sejenisnya sehingga indera penglihatan merupakan kekuatan gaya belajar ini (DePorter \& Hernacki, 2010). Oleh sebab itu, siswa yang memiliki gaya belajar visual mudah mengingat sesuatu yang dilihat.

Selain gaya belajar, perbedaan gender juga dapat menjadi salah satu faktor yang membedakan seseorang dalam berpikir dan menentukan penyelesaian masalah (Nur \& Palobo, 2018). Hal ini didukung dengan pernyataan Mayers-Levy (dalam Subarinah (2013)) bahwa terdapat terdapat perbedaan proses kognitif siswa laki-laki dan siswa perempuan dalam menyelesaikan masalah matematika. Selain itu, hasil penelitian Krutetski (dalam Adriani \& Zannah (2017)) menunjukkan bahwa "terdapat perbedaan antara siswa laki-laki dan perempuan, siswa laki-laki lebih baik dalam penalaran, sedangkan siswa perempuan lebih baik dalam hal ketepatan, ketelitian, kecermatan dan keseksamaan berpikir." Berdasarkan uraian di atas, maka peneliti melakukan penelitian dengan judul "Profil Berpikir Relasional Siswa Visual Berdasarkan Gender dalam Menyelesaikan Masalah Matematika". Adapun tujuan penelitian ini adalah untuk mendeskripsikan berpikir relasional siswa laki-laki dan perempuan yang memiliki gaya belajar visual dalam menyelesaikan masalah matematika.

\section{METODE}

Penelitian ini merupakan penelitian deskriptif kualitatif, yaitu penelitian yang bertujuan untuk memaparkan dan memahami keadaan sebenarnya dari subjek penelitian dengan ciri-ciri tertentu (Creswell, 2012). Data dalam penelitian ini diperoleh dari angket gaya belajar, soal tes, dan pedoman wawancara. Angket gaya belajar terdiri dari 21 butir pernyataan, yang terdiri dari tujuh butir untuk butir visual, tujuh butir untuk butir auditorial, tujuh butir untuk butir kinestetik. Kemudian, soal tes yang digunakan berupa soal uraian (essay) yang memuat materi sistem persamaan linear dua variabel (SPLDV). Terakhir, pedoman wawancara berisi pertanyaan yang berfungsi untuk memperkuat hasil tes penyelesaian masalah.

Penelitian ini dilaksanakan di SMP Negeri 6 Malang, tepatnya pada siswa kelas VIII-C. Kemudian, untuk subjek penelitian, peneliti membatasi sebanyak dua siswa, yaitu satu siswa laki-laki dan satu siswa perempuan yang memiliki gaya belajar visual dengan ketentuan telah menyelesaikan masalah yang diberikan dengan tuntas dan mampu berkomunikasi dengan baik. Setelah data terkumpul, selanjutnya peneliti melakukan proses analisis data menggunakan tiga alur kegiatan, yaitu reduksi data, penyajian data, dan penarikan kesimpulan. Hasil penelitian berupa temuan diperiksa keabsahannya kembali dengan teknik tiangulasi sumber yaitu dengan wawancara.

\section{HASIL}

Berdasarkan analsis pada angket gaya belajar, diperoleh siswa yang memiliki gaya belajar visual, auditortial, kinestetik, visual-auditorial, dan visual-kinestetik. Hasil tes gaya belajar tersebut dapat dilihat pada tabel 1. Selanjutnya, siswa diberikan soal penyelesaian masalah. Soal tes tersebut adalah satu soal cerita berkaitan dengan materi sistem persamaan linear dua variabel (SPLDV). Dari hasil tes penyelesaian masalah, rata-rata semua siswa dapat mengerjakan soal hingga diperoleh solusi. Namun, dari jawaban yang diberikan oleh siswa terdapat beberapa siswa yang terindikasi mencontoh temannya.

Berdasarkan hasil tes gaya belajar dan tes penyelesaian masalah, peneliti memilih dua siswa dengan gaya belajar visual yang masing-masing berjenis kelamin laki-laki dan perempuan yang telah menyelesaikan masalah yang diberikan dengan tuntas dan dapat berkomunikasi dengan baik sebagai subjek penelitian. Subjek tersebut disebut SVL dan SVP.

Tabel 1. Pengelompokkan Gaya Belajar Siswa

\begin{tabular}{lc}
\hline \multicolumn{1}{c}{ Gaya Belajar } & Jumlah Siswa \\
\hline Visual (V) & 8 \\
Auditorial (A) & 6 \\
Kinestetik (K) & 13 \\
Visual-Auditorial (V-A) & 2 \\
Visual-Kinestetik (V-K) & 3 \\
\hline \multicolumn{1}{c}{ Jumlah } & 32 Siswa \\
\hline
\end{tabular}

Adapaun indikator berpikir relasional yang digunakan dalam penelitian ini ialah dengan mengadaptasi indikator yang dikemukakan oleh Carpenter, dkk (2005), yaitu (1) siswa mampu melihat tanda sama dengan (=) sebagai simbol relasi; (2) siswa dapat fokus pada struktur ekspresi; (3) siswa dapat memberikan rasionalitas penggunaaan strategi. Berikut akan dijelaskan berpikir relasional siswa visual laki-laki dan siswa visual perempuan dalam menyelesaikan masalah. 


\section{Siswa Visual Laki-laki}

Proses penyelesaian masalah matematika yang dilakukan oleh siswa visual laki-laki (SVL) dapat dilihat pada gambar 1.

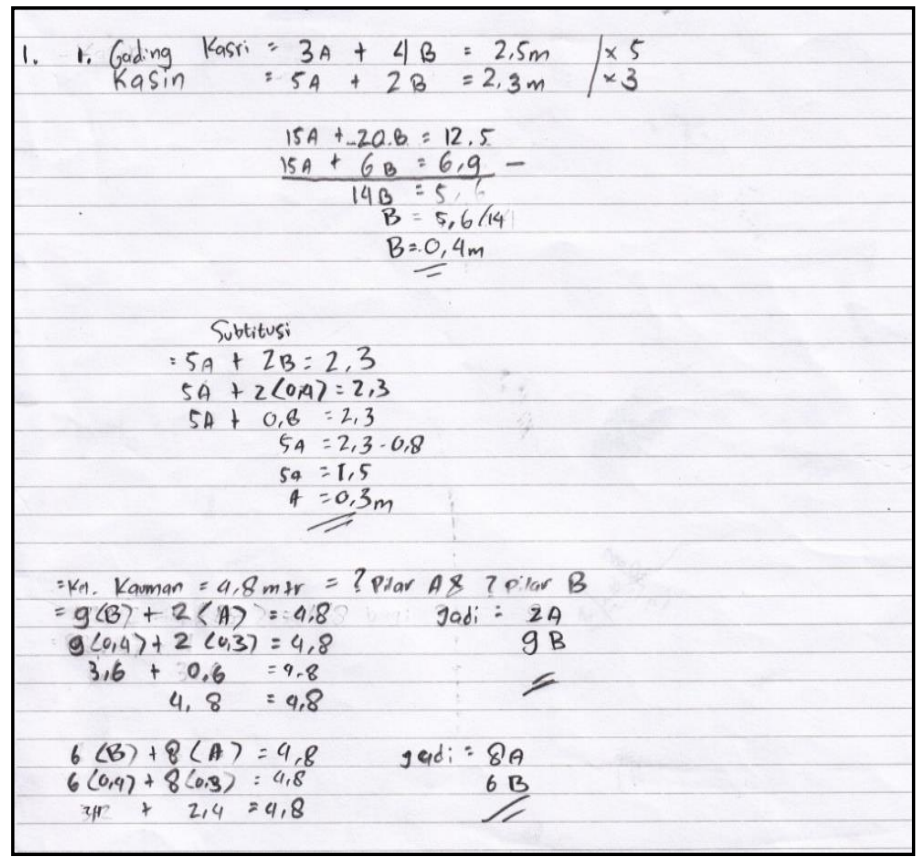

\section{Gambar 1. Proses Penyelesaian Masalah Siswa Visual Laki-laki (SVL)}

Berdasarkan gambar 1 dapat dilihat pemikiran relasional subjek SVL dalam menyelesaikan masalah. Hasil penyelesaian subjek SVL tersebut dapat dilihat bahwa siswa memenuhi indikator (1) dan (2) berpikir relasional karena pada proses penyelesaian tersebut siswa dapat melihat tanda sama dengan sebagi simbol relasi dan fokus pada struktur ekspresi. Dalam hal ini, siswa mampu merubah masalah dari bentuk cerita ke bentuk persamaan dengan menggunakan simbol aljabar dengan benar. Kemudian, siswa menyelesaikan masalah menggunakan konsep SPLDV dan operasi hitung, dan siswa dapat menyelesaikan masalah tersebut hingga tuntas dan memperoleh hasil yang benar. Siswa mencari nilai A dan nilai B menggunakan metode campuran (eliminasi-substitusi). Pada proses eliminasi, siswa mengeliminasi A dengan cara mengalikan persamaan pertama dengan bilangan 5 dan persamaan kedua dengan bilangan 3, kemudian dilakukan proses komputasi hingga diperoleh nilai B. Selanjutnya, siswa mencari nilai A dengan mensubstitusikan nilai B ke persamaan kedua. Setelah memperoleh nilai A dan B, siswa mencari pilar A dan B yang ditanyakan oleh soal dengan operasi hitung barupa operasi perkalian dan penjumlahan. Pada proses ini, siswa memperoleh dua kemungkinan, namun kemungkinan pertama yang diperoleh tidak tepat (salah).

Selain itu, siswa juga dapat memenuhi indikator (3) berpikir relasional karena siswa dapat memberikan alasan tentang cara yang digunakan untuk menyelesaikan permasahan yang diberikan. Hal tersebut tergambarkan pada wawancara yang dilakukan oleh peneliti. Berikut penggalan wawancara antara peneliti dengan SVL.

\begin{tabular}{|c|c|c|}
\hline$P$ & : & Apa saja yang diketahui dan ditanyakan dari soal ini? \\
\hline$S V L$ & . & $\begin{array}{l}\text { Yang diketahuinya itu, Kelurahan Gading Kasri menyusuan menara setinggi 2,5 m dengan } 3 \text { pilar A dan } 4 \text { pilar B. Kelurahan } \\
\text { Kasin menyusun meara setinggi } 2,3 \mathrm{~m} \text { dengan } 5 \text { pilar A dan } 2 \text { pilar B. Kelurahan Kauman menyusun meara setinggi 4,8 m. }\end{array}$ \\
\hline$P$ & : & $\begin{array}{l}\text { Setelah kamu mengetahui yang diketahui dan ditanyakan dari soal tersebut, apa yang kamu lakukan untuk menyelesaikan soal } \\
\text { tersebut? }\end{array}$ \\
\hline$S V L$ & & $\begin{array}{l}\text { Saya menggunakan cara campuran Bu. } \\
\text { Eliminasi dulu yang Kelurahan Gading Kasri dikurangi Kelurahan Kasin, itu yang A atau yang B nya dulu yang disamakan. } \\
\text { Kemudian, kalau sudah ketemu, hasilnya langsung substitusi ke salah satu persamaan itu. Setelah substitusi nanti akan ketemu } \\
\text { hasilnya. }\end{array}$ \\
\hline$P$ & : & Mengapa kamu melakukan hal tersebut? \\
\hline$S V L$ & & Untuk mencari nilai A dan nilai B yang merupakan panjang pilar A dan pilar B. \\
\hline$P$ & : & Kenapa kaтu memilih cara ini untuk menyelesaikan soal ini? \\
\hline$S V L$ & & Soalnya lebih mudah Bu kalau pake cara campuran. \\
\hline
\end{tabular}


Hasil wawancara menunjukkan bahwa SVL menggunakan konsep SPLDV untuk menentukan nilai A dan nilai B yang merupakan tinggi pilar A dan pilar B. SVL memilih menggunakan metode campuran (eliminasi-subtitusi) karena merasa lebih mudah menggunakan metode ini. Setelah mencari nilai A dan nilai B, selanjutnya SVL menentukan hal yang ditanyakan oleh soal, yaitu banyak pilar A dan pilar B yang dibutuhkan oleh Kelurahan Kauman.

\begin{tabular}{lll}
\hline $\boldsymbol{P}$ & $:$ & Setelah memperoleh nilai A dan B, apa yang kamu lakukan? \\
\hline$S V L$ & $:$ & Mencari pilar A dan pilar B nya Kelurahan Kauman Bu. \\
$P$ & $:$ & Bagaimana kamu mencarinya? \\
$S V L$ & $:$ & Dari mencoba-coba perkalian Bu, terus pake logika juga. \\
$P$ & $:$ & Kamu mencoba-coba seperti apa? \\
$S V L$ & $:$ & Berapa dikali dengan 0,3 terus ditambah berapa dikali dengan 0,4 hasilnya 4,8 \\
\hline
\end{tabular}

Berdasarkan wawancara, SVL menggunakan cara mencoba-coba untuk menentukan pilar A dan pilar B yang ditanyakan. Pada proses ini SVL mencoba-coba dengan cara mengalikan suatu bilangan dengan nilai A dan nilai B, kemudian hasil perhitungan tersebut dijumlahkan. Apabila diperoleh hasil 4,8 $\mathrm{m}$ (tinggi menara Kelurahan Kauman), maka bilangan tersebut merupakan pilar yang dibutuhkan oleh Kelurahan Kauman. Artinya, dalam proses ini siswa SVL harus mencoba banyak bilangan sehingga diperoleh hasil yang sesuai.

\section{Siswa Visual Perempuan}

Proses penyelesaian masalah matematika yang dilakukan oleh siswa visual perempuan (SVP) dapat dilihat pada gambar 2.

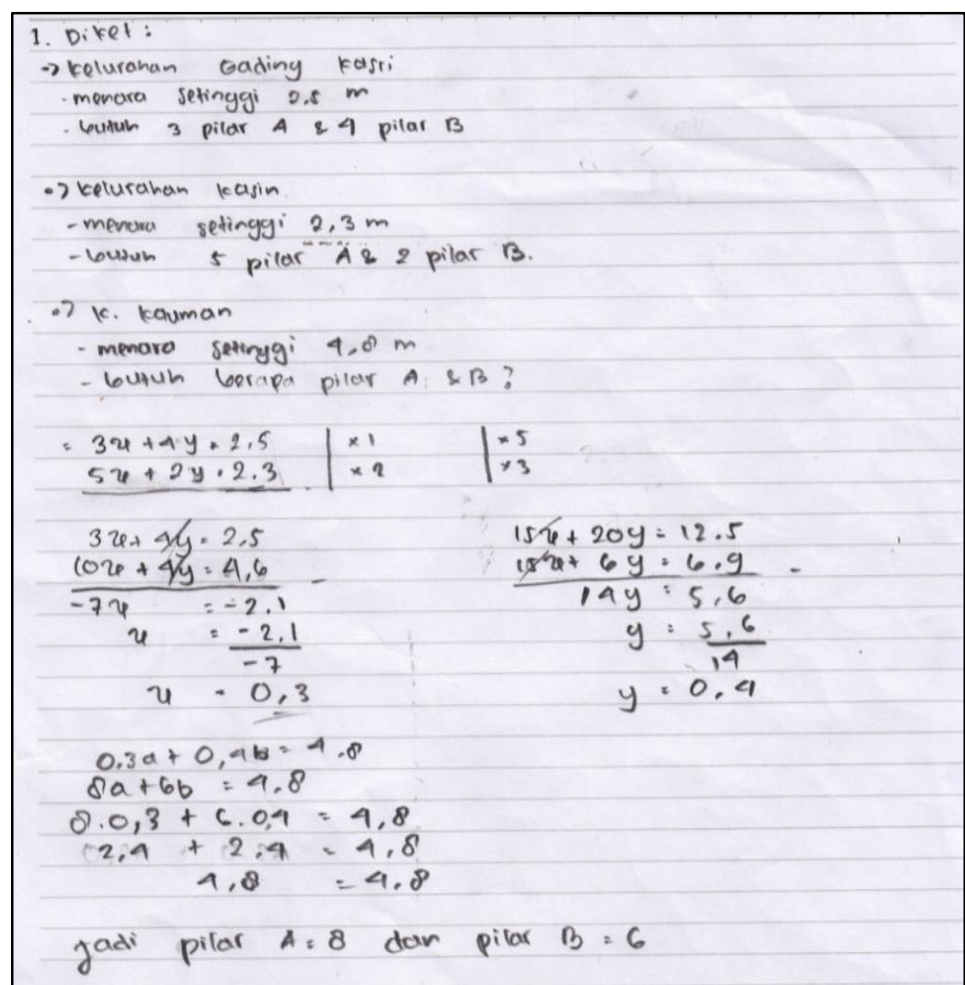

\section{Gambar 2. Proses Penyelesaian Masalah Siswa Visual Perempuan (SVP)}

Uraian jawaban SVP pada Gambar 1 menunjukkan bahwa siswa menuliskan unsur-unsur dalam masalah, seperti yang diketahui dan ditanyakan. Kemudian, siswa merubah unsur-unsur yang diketahui tersebut ke bentuk persamaan menggunakan simbol aljabar. Selanjutnya, dengan menggunakan konsep SPLDV dan operasi hitung, SVL menyelesaikan masalah tersebut hingga tuntas dan memperoleh hasil yang benar. Dalam hal ini, siswa mencari nilai variabel $x$ dan $y$ menggunakan metode eliminasi. Proses eliminasi pertama dilakukan oleh siswa untuk menentukan nilai variabel $x$ dengan mengalikan persamaan pertama dengan bilangan 1 dan persamaan kedua dengan bilangan 2, kemudian melakukan proses komputasi. Sementara pada proses eliminasi kedua, siswa mengalikan persamaan pertama dengan bilangan 5 dan persamaan kedua dengan bilangan 3 , kemudian melakukan proses komputasi. Hal ini menunjukkan SVP memenuhi indikator (1) dan (2) berpikir relasional karena pada proses penyelesaian tersebut siswa dapat melihat tanda sama dengan sebagai simbol relasi dan fokus pada struktur ekspresi. 
Siswa visual perempuan (SVP) juga memenuhi indikator (3) karena SVP dapat menjelaskan cara yang digunakan untuk menyelesaikan masalah dan alasan menggunakan cara tersebut. Hal tersebut dapat dilihat pada penggalan wawancara antara peneliti dengan SVP berikut ini.

\begin{tabular}{lll}
\hline $\boldsymbol{P}$ & $:$ & $\begin{array}{l}\text { Setelah mengetahui yang diketahui dan ditanyakan oleh soal, apa yang kamu lakukan untuk menyelesaikan soal } \\
\text { tersebut? }\end{array}$ \\
\hline$S V P:$ & Mencari nilai $x$ dan y menggunakan cara eliminasi \\
& $:$ & Kenapa kamu menggunakan cara eliminasi? \\
$P$ & $:$ & Karena saya lebih paham cara eliminasi daripada cara lainnya Bu. \\
$S V P$ & $:$ & Terus, nilai $x$ dan y yang kamu peroleh ini untuk apa? \\
$P$ & $:$ & Untuk menghitung pilar A dan pilar $B$ Bu. \\
\hline
\end{tabular}

Berdasarkan kutipan wawancara tersebut, SVP menjelaskan bahwa konsep SPLDV yang digunakan untuk menentukan nilai $x$ dan $y$ yang merupakan tinggi pilar A dan pilar B adalah metode eliminasi. Kemudian, alasan SVP menggunakan metode eliminasi ialah karena menurutnya metode ini lebih mudah jika dibandingkan dengan metode lain. Setelah mencari nilai $x$ dan nilai $y$, selanjutnya SVP menentukan hal yang ditanyakan oleh soal, yaitu banyak pilar A dan pilar B yang dibutuhkan oleh Kelurahan Kauman untuk menyusun menara.

\author{
$P \quad: \quad$ Setelah mencari nilai $x$ dan y, apa yang kamu lakukan? \\ SVP : $\quad$ Mencari banyak pilar A dan pilar B yang ditanyakan Bu. \\ $P \quad$ : Bagaimana kamu mencarinya? \\ SVP : $\quad$ Awalnya dari persamaan ini Bu (menunjuk persamaan baru). \\ Jadi, berapa dikali dengan 0,3 terus ditambah berapa dikali dengan 0,4 hasilnya 4,8
}

Berdasarkan wawancara, SVP memanfaatkan nilai $x$ dan $y$ yang diperoleh pada proses eliminasi dan tinggi menara yang diketahui pada soal untuk membentuk persamaan baru. Persamaan tersebut dapat dilihat pada gambar 2. Kemudian persamaan baru tersebut digunakan untuk menentukan banyak pilar A dan pilar B yang ditanyakan oleh soal.

\title{
PEMBAHASAN
}

Berdasarkan hasil penelitian, siswa visual laki-laki (SVL) maupun siswa visual perempuan (SVP) mampu melihat tanda sama dengan $(=)$ sebagai simbol relasi. Hal tersebut terlihat ketika siswa mengubah masalah dari bentuk soal cerita ke bentuk persamaan linear dua variabel menggunakan simbol aljabar, dan juga pada proses komputasi. Kemudian, siswa visual laki-laki (SVL) dan siswa visual perempuan (SVP) juga dapat fokus pada struktur ekspresi. Dalam hal ini, dari persamaan yang telah dituliskannya, siswa kemudian melakukan proses perhitungan menggunakan konsep SPDV untuk menentukan nilai variabel, kemudian menentukan hal yang ditanyakan dengan mempertimbangkan nilai yang diperoleh sebelumnya. Namun, pada proses ini, SVP melakukan kesalahan pada proses komputasi sehingga hasil yang diperoleh tidak sesuai. Ini menunjukkan berpikir relasional siswa laki-laki dan perempuan memiliki kesamaan, tetapi jika dilihat terdapat perbedaan pada indikator kedua, yaitu dapat fokus pada struktur ekspresi, dimana siswa laki-laki melakukan kesalahan karena kurang cermat, kurang teliti, dan lalai dalam melakukan perhitungan. Hal ini sejalan dengan penelitian Rafiah (2016) bahwa kefasihan siswa laki-laki untuk melihat kesalahan dan kekurangan dalam pemecahan masalah masih kurang. Selain itu, Susilowati (2016) juga mengungkapkan bahwa dalam menyelesaikan sesuatu, siswa laki-laki cenderung kurang teliti, terburu-buru, dan menggunakan cara yang singkat.

Perbedaan lain antara siswa laki-laki dan perempuan terletak pada penulisan informasi-informasi seperti yang diketahui dan ditanyakan dalam soal. Siswa laki-laki langsung menuliskan informasi-informasi tersebut dalam bentuk persamaan linear dua variabel, sedangkan siswa perempuan menuliskan informasi-informasi tersebut secara rinci kemudian menerjemahkannya dalam bentuk persamaan linear dua variabel. Perbedaan kedua terletak pada metode konsep SPLDV ketika mencari nilai variabel. Siswa laki-laki menggunakan metode campuran, sedangkan siswa perempuan menggunakan metode eliminasi. Perbedaan penggunaan metode pada operasi hitung ketika menentukan hal yang ditanyakan soal serta kemungkinan hasilnya. Perbedaan-perbedaan tersebut menunjukkan bahwa setiap siswa memilki cara berpikir yang berbeda dalam menyelesaikan masalah. Hal ini disebabkan karena masing-masing orang mempunyai cara berbeda-beda dalam menyerap informasi (DePorter \& Hernacki, 2010). Selain itu, setiap siswa memiliki perlakuan yang sama saat pembelajaran, namun setiap siswa memiliki pemahaman, pemikiran, dan pandangan yang berbeda saat menerima informasi (Natalia, 2011).

Kemudian, dari proses penyelesaian yang dilakukan, siswa visual laki-laki maupun perempuan dapat memberikan rasionalitas penggunaan strategi untuk menyelesaikan masalah. Melalui wawancara, siswa dapat mengungkapkan konsep yang digunakan untuk menyelesaikan masalah dan alasan menggunakan konsep tersebut. Siswa juga mampu memilih dan menjelaskan penggunaan operasi hitung dan relasi. Dalam hal ini, siswa mampu memilih strategi penyelesaian masalah dengan benar. Oleh karena itu, siswa dapat menyelesaikan masalah dengan hingga tuntas dan benar. Ketika siswa mampu memberikan alasan dari konsep atau prinsip yang digunakan dalam menyelesaikan masalahnya, maka siswa tersebut tergolong menggunakan pemikiran relasional (Nasir, 2018). 


\section{SIMPULAN}

Berdasarkan hasil analisis data dan pembahasan, maka dapat disimpulkan bahwa profil berpikir relasional siswa visual laki-laki dan siswa visual perempuan dalam menyelesaikan masalah matematika memiliki kesamaan, yaitu mampu melihat tanda sama dengan (=) sebagai simbol relasi, dapat fokus pada struktur ekspresi, dan dapat memberikan rasionalitas penggunaan strategi untuk menyelesaikan masalah matematika. Namun, terdapat perbedaan antara siswa visual laki-laki dan siswa visual perempuan pada indikator kedua, dimana siswa laki-laki belum sepenuhnya fokus pada struktur ekspresi, dimana siswa melakukan kesalahan komputasi. Artinya, perbedaan profil berpikir relasional siswa terletak pada ketelitian dan kecermatan, bukan dari ide, jawaban, atau penyelesaian yang dihasilkan. Penelitian ini masih terbatas pada subjek yang memiliki gaya belajar visual saja sehingga untuk memperkaya tinjuan maka dapat dilakukan penelitian lanjutan pada subjek bergaya belajar lainnya atau dari beberapa aspek kemampuan matematis lainnya.

\section{DAFTAR RUJUKAN}

Amir, Z. (2013). Perspektif Gender dalam Pembelajaran Matematika. Marwah, XII(1),14_31.

Baiduri, Budayasa, K., Lukito, A., \& Sutawijaya, A. (2013). Analisis Proses Berpikir Relasional Siswa Sekolah Dasar Membuat Perencanaan Penyelesaian Masalah Matematika (Kasus Siswa Berkemampuan Matematika Rendah). Prosiding Konferensi Nasional Pendidikan Matematika V, 310-323. Malang: FMIPA, Universitas Negeri Malang.

Carpenter, T.P., Franke, M. L., Madison, Levi, L., \& Zeringue, J. K. (2005). Algebra in Elementary Schooll: Developing Relational Thinking. ZDM: Mathematics Education, 37(1), 53-59.

Creswell, J. W. (2012). Educational Research “Planning, Conducting, and Evaluating Quantitative and Qualitative Research". Amerika: Pearson.

DePorter, B. \& Hernacki, M. (2010). Quantum Learning: Membiasakan Belajar Nyaman dan Menyenangkan. Bandung: Kaifa.

Garner, O. L. \& Harrison, S. (2013). An Investigation of the Learning Style and Study Habits of Chemistry Undergraduate in Barbados and their Effect and Predictors of Academic Achivement in Chemical Group Theory. Journal of Education and Social Research, 2(3), 107-122.

Hejný, M., Jirotková, D. \& Kratochvilová, D. (2006). Early Conceptual Thinking”. In Novotná, J., Moraová, H., Krátká, M. \& Stheliková, N. (Eds.). Proceedings $30^{\text {th }}$ Conferences of the International Group for the Psychology of Mathematics Education, 3, 289-296. Prague: PME.

Indrawati, R. (2017). Profil Pemecahan Masalah Matematika Ditinjau dari Gaya Belajar. APOTEMA: Jurnal Program Studi Pendidikan Matematika, 3(2), 91-100.

Molina, M., Castro, E., \& Mason, J. (2008). Elementary School Students' Approaches to Solving True/False Number Sentences. PNA, 2(2), 75-86.

Nasir, M. A. (2016). Analisis Pemahaman Relasional Siswa SMA dalam Menyelesaikan Masalah Geometri. Tesis tidak diterbitkan. Universitas Negeri Malang, Malang.

Natalia, T. (2011). Hubungan Gaya Belajar dengan Prestasi Belajar Siswa Kelas IV di Sekolah Dasar Gugus Diponegoro pada Tahun Ajaran 2010/2011. Skripsi tidak diterbitkan. UKSW Salatiga, Semarang.

National Council of Teachers of Mathematics. (2000). Principles and Standards for School Mathematics. Virginia: NCTM.

Nur, A. S., \& Palobo, M. (2018). Profil Kemampuan Pemecahan Masalah Matematika Siswa Ditinjau dari Perbedaan Gaya Kognitif dan Gender. KREANO: Jurnal Matematika Kreatif-Inovatif, 9(2), 139-148.

Rafiah, H. (2016). Profil Berpikir Kreatif Matematis Siswa Kelas VI Berdasarkan Gender dalam Pemecahan Masalah Openended. Tesis tidak diterbitkan. Universitas Negeri Malang, Malang.

Stephens, M. (2006). Describing and Exploring the Power of Relational Thinking”. In P. Grootenboer, R. Zevenbergen, \& M. Chinnappan (eds.), Identities, Cultures and Learning Spaces, Proceeding of the 29th annual conference of the Mathematics Education Research Group of Australasia, 479-486. Canberra: MERGA.

Subarinah, S. (2013). Profil Berpikir Kreatif Siswa dalam Memecahkan Masalah Tipe Investigasi Matematik Ditinjau dari Perbedaan Gender. Prosiding Seminar Nasional Matematika dan Pendidikan Matematika, 541_548, Yogyakarta: Jurusan Pendidikan Matematika, FMIPA, UNY.

Sugiyono. (2009). Metode Penelitian Kuantitatif, Kualitatif, dan R\&D. Bandung: Alfabeta.

Susilowati, J. P. A. (2016). Profil Penalaran Siswa SMP dalam Pemecahan Masalah Matematika Ditinjau dari Perbedaan Gender. Jurnal Review Pembelajaran Matematika (JRPM), 1(2), 132-148.

Zalyanty, M. (2016). Kemampuan Pemecahan Masalah Siswa dengan Gaya Belajar Introvert-Ekstrovert dalam Memecahkan Masalah Matematika. Tesis tidak diterbitkan. Universitas Negeri Malang, Malang. 